\title{
COMMISSION 20. (MINOR PLANETS, COMETS AND SATELLITES)
}

\author{
President: Prof. A. O. Leuschner. \\ SeCretary: Miss J. M. Vinter Hansen.
}

I. 'Joint meeting of Commissions 6 and 20 on Thursday morning, July II.

The cipher code for astronomical telegrams (relating to the description of objects and other matters) proposed by the President of Commission 6 (Prof. Strömgren) was discussed and accepted, with minor alterations. (See report of meeting of Commission 6, page 289; also the cipher code adopted, page 39r.)

2. Joint meeting of Commissions 4,8 and 20 on Thursday afternoon, July Ir. (See also reports of meetings of Commissions 4 and 8, pages $28 \mathrm{I}$ and 290.)

The proposals of Noumerov (Leningrad) and Brouwer for the determination of systematic corrections to star positions from observations of minor planets were discussed, and the following resolution passed for action by the General Assembly. "Commissions 4, 8 and 20 recommend that the programme of $M$. Noumerov for the determination of systematic corrections to star positions from observations of minor planets and the similar programme advanced by $\mathrm{Mr}$ Brouwer be encouraged as being of great importance, but that the formation of a subcommittee of one of the existing commissions or of an independent commission for the co-ordination of the two programmes and the promotion of international co-operation of observatories and planet institutes or almanac offices be deferred pending the outcome of the experimental stages of the two programmes."

3. Joint meeting of Commissions 4 and 20 on Friday morning, July I2, for the discussion of a standard equinox and whether or not supplementary data should be given by the almanacs.

The Chairman (Prof. Leuschner) called attention to the fact that, at the joint meeting of Commissions 6 and 20 on July II, it had been decided to adhere to the equinox of the beginning of the current year for observations in the discovery appearance or first opposition of comets and minor planets and for preliminary orbits. After full discussion the proposal of Commission 4 for the adoption of I950.0 as a standard equinox was accepted for action by the General Assembly, subject to the following reservations:*

(a) In view of the desire of approximately one half of the observers and computers interested in minor planets and comets it is suggested, on behalf of Commission 20, that the proposed resolution (Reports, pages 29 and I36) should not apply to observations during the discovery appearance or first opposition or to preliminary orbits. Commissions 6 and 20 have agreed to continue the equinox of the beginning of the current year for telegraphic positions, and have provided in the code for the announcement of positions for other equinoxes, such as $1950^{\circ} 0$ or $1900^{\circ} 0$.

(b) It is suggested that, for the present, some of the almanacs continue publication of the data necessary for preliminary orbits referred to the equinox of the beginning of the year, in addition to giving data for the equinox of $195^{\circ} 0$.

Prof. Kopff and Dr Robertson stated that these data were being continued in the Berliner Jahrbuch and in the American Ephemeris, and Dr Comrie announced that they would be restored in the Nautical Almanac.

- For the final form of the resolutions see report of meeting of Commission 4, p. 283. 
As regards other data desirable in the almanacs the following proposals were made on behalf of Commission 20:

(a) It seems desirable to continue the solar co-ordinates to seven decimals, as this accuracy is essential for orbit computations of objects approaching close to the Earth.

This was accepted as an expression of opinion of the joint meeting. Dr Comrie and Dr Robertson remarked that the Nautical Almanac and the American Ephemeris both gave the solar co-ordinates to seven decimals.

(b) It is recommended that Commission 4 give early consideration to a formulated plan for the correction of the elements of the major planets, particularly of the Earth. In the meantime the publication in the almanacs of the correction to the observed time for the interpolation of the solar co-ordinates to take up the error in longitude would be helpful.

For the discussion of this topic see report of meeting of Commission 4, page 284 .

The following resolution was passed to go before the General Assembly: "It is desirable that the calculation and publication of accurate ephemerides of the first four minor planets should be undertaken and, if necessary, shared by various almanacs."

Prof. Leuschner pointed out that, in investigations of the motion of bodies over long periods, a complete historical record of all changes that have been made in the almanacs since their inception was needed, particularly as regards tables of the Sun and major planets and astronomical constants, and urged the directors to provide such records. Prof. Brown thought this highly desirable, especially for the Sun and Moon, but considered that it should be done by Commission 5. Prof. Leuschner stated that he would confer with the President of Commission 5 concerning the matter.

4. Meeting of Saturday morning, July I3.

The President described the work done by Dr Bower (Berkeley) for producing tables of the solar and planetary co-ordinates for 1900.0 similar to those published by the Nautical Almanac for I950.0. A copy of the Nautical Almanac tables was circulated, and the President called attention to the table of contents, which follows:

Co-ordinates of Venus, Earth and Mars, I900-1940.

Co-ordinates of Jupiter and Saturn, 1800-1940.

Co-ordinates of Uranus and Neptune, 1903-1940.

Table I. Mean obliquity.

Table II. Ecliptic precessional elements.

Table III. Equatorial precessional elements.

Table IV. Equatorial precessional elements.

Table V. Reduction of equatorial rectangular co-ordinates.

Table VI. Reduction of star positions I875-1950.

Table VII. Reduction of star positions I900-I950.

Table VIII. Reduction of star positions I925-r950.

Table IX. Coefficients for commencing integration schemes.

Table X. Table of $\frac{\mathbf{I}}{r^{3}}$ with argument $r^{2}$.

Table XI. Table of $f$ with argument $q$.

Table XII. Values of $\frac{\mathrm{IO}^{2} m k^{2} 10^{7}}{\rho^{2}}$.

Table XIII. Lagrange interpolation coefficients.

Table XIV. Formulae.

Table XV. Masses and attractions. 
The state of Bower's co-ordinate tables for the equinox of $I 900.0$ is as follows. He has computed:

(a) The heliocentric equatorial co-ordinates of Jupiter at 80-day intervals, I900-I94I; of Saturn at I60-day intervals, I900-r94I; of Uranus and Neptune at 320-day intervals, I903-I94I, as accurately as the ephemerides allow.

(b) The barycentric equatorial co-ordinates of the Sun (augmented by masses interior to Jupiter), Jupiter, Saturn, Uranus and Neptune at Ioo-day intervals, I903-I94I. The adopted barycentre is the centre of mass of Sun (augmented), Jupiter, Saturn, Uranus and Neptune.

The tables are finished, except for subdivision, which can readily be accomplished by recently developed machine methods. The members of the Commission were asked to express their opinion whether or not the completion and publication of the tables should be encouraged. Some members pointed out that the Igoo tables were superfluous, as the Nautical Almanac tables gave all data for the reduction of star positions to I950.0 from any other equinox. Others felt that the tables should be completed to facilitate the work of investigators who desire to use positions obtained from the astrographic catalogue and thus avoid the frequent errors by observers when reducing to other equinoxes. The following resolution was unanimously adopted: "The availability of tables of the solar and planetary co-ordinates for the equinox of I900.0 would be welcomed by those computers who prefer to base their computations primarily on $1900^{\circ} 0$ astrographic positions, pending the availability of catalogues and charts for $I 95^{\circ} \circ$, and the Commission hopes that the tables for I900.0 under way by Dr Bower may be completed and published."

As a result of existing unsatisfactory conditions in the publication of final positions of minor planets, comets and satellites the Commission, after prolonged discussion, unanimously adopted the following resolution for action by the General Assembly: "In view of the difficulties that have been experienced by orbit computers as a result of erroneous reductions made by observers, it is recommended that, in the case of visual observations, the observer should publish the measured differences, object minus comparison star, together with the adopted position of the comparison star and the reduction for differential aberration, nutation and precession. In the case of photographic observations depending on a few stars only, the adopted positions of the stars should be published, together with the dependence, to at least two decimals, of each star with respect to the moving object."

This resolution is in accordance with the practice of a number of observers, at Uccle and elsewhere (cf. Bulletin Astronomique de l'Observatoire Royal de Belgique, for example).

The President reported that it had been suggested that the eccentricity term in the aberration should be taken into account in the publication of accurate positions, in order to facilitate definitive investigation of orbits and perturbations. This was supported by Dr Comrie. After full discussion the following resolution was unanimously carried for action by the General Assembly: "Commissions 4, 8 and 20 are requested to consider the advisability of restoring to positional astronomy the term in the annual aberration depending on the eccentricity of the Earth's orbit, and to report at the next meeting of the Union."

Dr Crommelin reported on behalf of the subcommittee on periodic comets, and described the work done by the British Astronomical Association. The Commission requested him to call a meeting of his subcommittee for discussion of a plan to avoid duplications and omissions of needed predictions. Prof. Kopff drew attention to the summary given for over 30 years by Prof. Kobold, of Kiel. 
Prof. Brown reported that he and Dr Brouwer have prepared a general theory of Jupiter's eighth satellite, and will also compare the theory with observations. In collaboration with Dr Eckert he intends to recalculate the solar terms in the motion of the Moon, and the motion of the perigee.

\section{Meeting on Tuesday, July 16.}

The President suggested that the General Assembly be requested to change the name of the Commission to "Commission pour l'observation des positions et des mouvements des petites planètes, des comètes, et des satellites". This suggestion had already been discussed with several members of the Commission. The change would have the advantage of taking into account the varied activities of the Commission, especially as there now no longer existed a commission on celestial mechanics. This motion was proposed by Dr Comrie, seconded by Dr Crommelin and carried unanimously.

Commenting on the resolutions carried at joint sessions with other commissions, the President drew attention to the fact that the resolutions in regard to the equinox in their present forms referred only to comets, and said he had no doubt that the Commission would agree that these resolutions should apply equally to minor planets. Dr Comrie, as President of Commission 4, spoke in favour of this motion, which was then carried.

Dr Crommelin presented the following report on behalf of the subcommittee on periodic comets: "The subcommittee appointed to arrange for the calculation of orbits and ephemerides of periodic comets and for avoiding duplications or omissions recommends that astronomers who undertake definitive calculations should make their intention known in advance to the secretary of the subcommittee, who will be responsible for distributing the information through the Central Bureau for Astronomical Telegrams, the Harvard College Announcement Cards, the Journal of the British Astronomical Association, the Beobachtungs-Zirkulare der Astronomischen Nachrichten, and other media. If under the foregoing plan elements and ephemerides are not forthcoming for a comet, the Central Bureau and the British Astronomical Association are urged to provide, by mutual understanding, the necessary calculations and to keep the secretary informed. The British Astronomical Association offers to include in its annual Handbook all predictions received by August $3 I$ of the year preceding that for which the Handbook is published."

This report was adopted, and a resolution passed requesting the General Assembly to provide for a subcommittee on periodic comets in accordance with the foregoing report.

The Commission then proceeded to consideration of the topics listed in its report (page I36).

(I) The question of systematic correction of star positions from observations of minor planets having been disposed of at a joint meeting with Commissions 4 and 8 (see page 284), further discussion was waived.

(2) The President submitted Circular 980 of the Astronomisches Rechen-Institut, issued on I934 May I9, concerning the numbering of minor planets and the designation of discoverers, with the following statement: "The plan published by the Astronomisches Rechen-Institut for the numbering of minor planets and the designation of discoverers was placed on the agenda for the information of the Commission at the suggestion of Prof. Kopff. No action is considered necessary at this time beyond an understanding that astronomers desiring to comment on the 
plan should address their views direct to the Rechen-Institut." The Circular (translated) is as follows.

As misunderstandings concerning the numbering and discoverers of planets frequently arise, we desire to bring the following standard procedure to the attention of all interested.

Procedure for the Numbering of Planets.

(i) The planet is observed only at the discovery apparition. The planet is numbered if the elements represent at least five well-distributed observations, extending over a period of at least six weeks, within a few seconds of arc in each co-ordinate.

A greater number of well-distributed observations is, however, highly desirable. If more than five observations distributed over a period of at least six weeks are available, the planet is numbered, even if some of the observations show fairly large residuals. It is, of course, taken for granted that it is evident from the run of the remaining residuals that the badly-deviating observations are in error. Even if the above conditions are fulfilled, the planet is not numbered if the discovery apparition occurred several years previously.

(ii) The planet is observed at more than one apparition. The planet is numbered, even if the conditions mentioned in (i) are not fulfilled,

(a) if an unnumbered planet is found at a second apparition. If the resultant elements do not represent the observations of the second apparition sufficiently well, the orbit is corrected if perturbations are being taken into account; empirical correction of the mean motion is not sufficient;

(b) if the unnumbered planet is identified with another unnumbered planet. The number is assigned to the planet that has yielded the better elements. If the orbit derived for one of the planets represents the observations of the other sufficiently accurately, no correction is made, even when the orbit is derived from shorter intervals. In the case of large deviations the orbit is corrected if perturbations are being taken into account; empirical correction of the mean motion is not sufficient. The number is assigned to the planet whose observations have contributed most to the definition of the orbit; the same principle governs cases where more than two planets are identical with one another.

(iii) The discoverev of a planet is the observer who has found a planet independently at the earliest point of time. The observer first announcing the discovery does not therefore automatically rank as its discoverer. All observers are asked to announce their discoveries as soon as possible, in order to avoid any ambiguity. The apparition that led to the numbering ranks as the discovery apparition. (Compare (ii) (b).)

Dr Delporte directed particular attention to Section 3, and urged astronomers to report their discoveries promptly to the Rechen-Institut, so that no doubt may arise about the priority of a discovery.

(3) Modifications of the telegraphic code for the description of comets, etc., to take effect on I935 November 1 , having been adopted at a joint meeting of Commissions 6 and 20 (see page 289), no further proposals were considered. The new code assigns the figure o for "stellar appearance"; provides for referring positions to an equinox other than that of the beginning of the current year, such as $1900 \cdot 0$ or I950.0; gives the right ascension in hours, minutes and seconds (tenths of seconds in accurate positions, tenths of minutes in approximate positions); gives the declination instead of the polar distance; and gives the daily motion in right ascension in minutes and seconds of time.

(4) The President stated that, in the printed report, he had not suggested any particular modifications in the material published annually in Kleine Planeten, as he 
had not then had an opportunity of discussing this matter with Prof. Kopff. However, he now put forward the following memorandum: "The President has recently discussed with the Director of the Astronomisches Rechen-Institut certain future modifications of the content and of the arrangement of material released annually in Kleine Planeten, with the object of supplementing the excellent service rendered to observers by such information concerning the significance of all published elements as is required by investigators of accurate special or general perturbations. Prof. Kopff stands ready to co-operate as far as financial resources permit. In view of the practice of printing the elements and other data years in advance of publication, and of other complications requiring consideration by Prof. Stracke, it is considered advisable to leave further negotiations to the President, Prof. Kopff and Prof. Stracke."

(5) In connection with the proposed stimulation of the development of general perturbations on the basis of accurate osculating elements, Prof. Leuschner gave an outline of the present practices for computing special and general perturbations, paying particular attention to the degree of accuracy obtained by using approximate basic elements as taken from Kleine Planeten and by using accurate osculating. elements. He pointed out the danger that accurate elements may suffer by adjustment on the basis of approximate perturbations, and gave examples of unsatisfactory results obtained in this way. He suggested that the Commission should take a definite position in regard to this question, and that, for the time being, the pronouncement that "It is eminently desirable that more attention be given to the development of accurate general perturbations and mean elements on the basis of accurate osculating elements" would probably be all that was necessary to influence astronomers in the right direction. The Astronomisches Rechen-Institut has already adopted the general perturbations of more than 200 minor planets, and it can be confidently relied upon to use others, if made readily available. He then referred to the recent successful application of the Berkeley Tables for the Hecuba Group (mean motion twice that of Jupiter) in the determination of the mean elements and general perturbations of eight difficult minor planets, using accurate basic elements, osculating with one exception in the latter half of last century. Without the intervening calculations necessary in special perturbations, the theoretical positions, as published in Lick Observatory Bulletin 469, showed a highly satisfactory agreement with recent observations. Since about one quarter of the minor planets belong to this group, and since other commensurable cases can be treated by special tables based on Bohlin's group method, while Hansen's, Gyldén-Brendel's and other methods are also available, the task of producing general perturbations with more or less accuracy for all the minor planets seemed not nearly so hopeless as had been generally assumed. It remained, of course, to perform the mechanical task of tabulating such general perturbations, which can be done with the degree of accuracy demanded for various purposes-approximately only if for finding ephemerides. For a source of accurate osculating elements which have long been discarded, he referred to his Research Surveys of the Orbits and Perturbations of IogI Minor Planets, which was on exhibition during the meeting of the Union. He referred also to the vast amount of work done at the Frankfurt Planeten-Institut, on the original initiative of Charlier, and by Villemarqué (ZO-Se) in deriving general perturbations without, however, basing them on the best osculating elements, and thus failing to achieve in all cases the accuracy that might otherwise have been attained.

Prof. Kopff agreed with the proposed pronouncement, but considered it sufficient for the purposes of Kleine Planeten to have approximate special or general pertur- 
bations. There being no objection, it was decided to include the above pronouncement in the record of the meeting.

Prof. Kepinski proposed that astronomers be asked to inform the Commission of any plan they have for the development of accurate general perturbations of a particular minor planet, so that duplication may be avoided. Prof. Leuschner agreed that the information hitherto sent to the Rechen-Institut should also be sent to him at Berkeley, where much material has been collected, and added that he was in favour of a certain amount of duplication, as he considered it highly important to compare the results obtained by different methods. With this understanding, Prof. Kepiński's proposal was accepted.

(6) Prof. Leuschner emphasised the advisability of publishing future osculating elements based on accurate special perturbations for a fixed date each year, in order to facilitate comparison of different elements and ephemerides. He stated that Dr Comrie had suggested that the fixed dates be 400 days apart, being the Greenwich midnights for which the integral part of the Julian Day is divisible by 400 . For 1935 and 1936 the fixed dates would be:

$$
\begin{aligned}
& \text { I935 July I7•0 U.T. }=\text { J.D. } 2428000 \cdot 5 \\
& \text { I936 Aug. 20.0 U.T. }=\text { J.D. } 2428400 \cdot 5 \cdot
\end{aligned}
$$

He mentioned that the osculating date need never be more than 200 days from the middle of the period over which a new object was observed. He illustrated the utility of the adoption of the same published epoch of osculation by referring to the discussion of the orbits and perturbations of (79) Eurynome in the introduction to the forthcoming Research Surveys. From three independent sets of elements with approximately the same epoch of osculation derived by Rogers, Tischler and Watson from different normal places in the first opposition (I863-64), and from corresponding residuals for the same date in the next opposition, with accurate special perturbations by Jupiter and Saturn, he had interpolated a mean motion and corresponding elements which agreed closely with the mean motion and elements by Lachmann resulting from a fourth independent investigation covering eleven oppositions over eighteen years. From this result, he said, the conclusion may be drawn that the rapidity of attaining fundamental osculating elements and their accuracy may be enhanced by the comparative study of parallel investigations.

Dr Comrie suggested that, if 400 days was too long an interval, the intermediate 200-day dates could be used. Dr Crommelin agreed that smaller intervals would have to be used for comets, and Prof. Kopff also thought that smaller intervals might be necessary in special cases, though he agreed with the general proposal.

Prof. Leuschner explained that the question was not one of the intervals necessary for the computation of special perturbations of a particular minor planet or comet, but of agreement to adopt fixed epochs for the publication of osculating elements, irrespective of such additional epochs as the computer might find convenient. The Commission then voted unanimously to announce its recommendation for fixed epochs of osculation at Julian dates of which the integral part is divisible by 400. Beginning with I900 the dates are as shown in the table on page 316.

(7) The President opened the discussion on the limitation to once in five years of opposition ephemerides for certain minor planets by saying that the inclusion of this item on the agenda was the result of informal statements made to him by different astronomers from time to time. It was thought that the proposal would stimulate 
the observation of fainter planets which, according to published statements of the Astronomisches Rechen-Institut, are now somewhat neglected; also for many planets observations are no longer needed at every opposition. The brighter asteroids are more often observed than the fainter ones; on the other hand many astronomers want ephemerides of the brighter planets for photometric work. He went on to say that the Rechen-Institut intends to continue annual publication of the ephemerides, and that the time was hardly ripe for a definite pronouncement. Dr Comrie pointed out what he considered to be a contradiction in the proposal under discussion, in that it made provision for providing data for the identification of images of minor planets on photographic plates, although publication of opposition ephemerides was to be limited to once in five years. Dr Crommelin suggested that at least one position, with corresponding rates of motion, should be given each

\begin{tabular}{|c|c|c|c|c|}
\hline J.D. & U.T. & G.M.T. & J.D. & U.T. $=$ G.M.T. \\
\hline $\begin{array}{r}2415200 \cdot 5 \\
5600 \cdot 5 \\
6000 \cdot 5 \\
6400 \cdot 5 \\
6800 \cdot 5\end{array}$ & $\begin{array}{l}1900 \text { June } 30 \cdot 0 \\
1901 \text { Aug. } 4 \cdot 0 \\
1902 \text { Sept. } 8 \cdot 0 \\
1903 \text { Oct. } 13 \cdot 0 \\
1904 \text { Nov. } 16 \cdot 0\end{array}$ & $\begin{array}{l}\text { June } \mathbf{2 9 \cdot 5} \\
\text { Aug. } \quad \mathbf{3 \cdot 5} \\
\text { Sept. } \mathbf{7 \cdot 5} \\
\text { Oct. } \mathbf{1 2 \cdot 5} \\
\text { Nov. } \mathbf{1 5 \cdot 5}\end{array}$ & $\begin{array}{r}2424400 \cdot 5 \\
4800 \cdot 5 \\
5200 \cdot 5 \\
5600 \cdot 5 \\
6000 \cdot 5\end{array}$ & $\begin{array}{l}1925 \text { Sept. } 7 \cdot 0 \\
1926 \text { Oct. } 12 \cdot 0 \\
1927 \text { Nov. } 16 \cdot 0 \\
1928 \text { Dec. } 20 \cdot 0 \\
1930 \text { Jan. } 24 \cdot 0\end{array}$ \\
\hline $\begin{array}{r}2417200 \cdot 5 \\
7600 \cdot 5 \\
8000 \cdot 5 \\
8400 \cdot 5 \\
8800 \cdot 5\end{array}$ & $\begin{array}{l}1905 \text { Dec. } 21 \cdot 0 \\
1907 \text { Jan. } 25 \cdot 0 \\
1908 \text { Feb. } 29 \cdot 0 \\
1909 \text { Apr. } 4 \cdot 0 \\
1910 \text { May } 9 \cdot 0\end{array}$ & 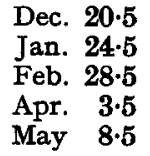 & $\begin{array}{r}2426400 \cdot 5 \\
6800 \cdot 5 \\
7200 \cdot 5 \\
7600 \cdot 5 \\
8000 \cdot 5\end{array}$ & $\begin{array}{l}1931 \text { Feb. } 28 \cdot 0 \\
1932 \text { Apr. } 3 \cdot 0 \\
1933 \text { May } 8 \cdot 0 \\
1934 \text { June } 12 \cdot 0 \\
1935 \text { July } 17 \cdot 0\end{array}$ \\
\hline $\begin{array}{r}2419200 \cdot 5 \\
2419600 \cdot 5 \\
2420000 \cdot 5 \\
0400 \cdot 5 \\
0800 \cdot 5\end{array}$ & $\begin{array}{l}1911 \text { June } 13 \cdot 0 \\
1912 \text { July } 17 \cdot 0 \\
1913 \text { Aug. } 21 \cdot 0 \\
1914 \text { Sept. } 25 \cdot 0 \\
1915 \text { Oct. } 30 \cdot 0\end{array}$ & $\begin{array}{l}\text { June } 12 \cdot 5 \\
\text { July } 16 \cdot 5 \\
\text { Aug. } 20 \cdot 5 \\
\text { Sept. 24.5 } \\
\text { Oct. } 29 \cdot 5\end{array}$ & $\begin{array}{r}2428400 \cdot 5 \\
8800 \cdot 5 \\
9200 \cdot 5 \\
2429600 \cdot 5 \\
2439000 \cdot 5\end{array}$ & $\begin{array}{l}1936 \text { Aug. } 20 \cdot 0 \\
1937 \text { Sept. } 24 \cdot 0 \\
1938 \text { Oct. } 29 \cdot 0 \\
1939 \text { Dec. } \\
1941 \text { Jan. } \\
\text { 6.0 }\end{array}$ \\
\hline $\begin{array}{r}2421200 \cdot 5 \\
1600 \cdot 5 \\
2000 \cdot 5 \\
2400 \cdot 5 \\
2800 \cdot 5\end{array}$ & $\begin{array}{l}1916 \text { Dec. } 3.0 \\
1918 \text { Jan. } 7 \cdot 0 \\
1919 \text { Feb. } 11 \cdot 0 \\
1920 \text { Mar. } 17.0 \\
1921 \text { Apr. } 21.0\end{array}$ & $\begin{array}{lr}\text { Dec. } & \mathbf{2 \cdot 5} \\
\text { Jan. } & \mathbf{6 \cdot 5} \\
\text { Feb. } & \mathbf{1 0 \cdot 5} \\
\text { Mar. } \mathbf{1 6 \cdot 5} \\
\text { Apr. } 20.5\end{array}$ & $\begin{array}{r}2430400.5 \\
0800.5 \\
1200.5 \\
1600.5 \\
2000 \cdot 5\end{array}$ & $\begin{array}{l}1942 \text { Feb. } 10 \cdot 0 \\
1943 \text { Mar. } 17 \cdot 0 \\
1944 \text { Apr. } 20.0 \\
1945 \text { May } 25 \cdot 0 \\
1946 \text { June } 29 \cdot 0\end{array}$ \\
\hline $\begin{array}{r}2423200 \cdot 5 \\
3600 \cdot 5 \\
4000 \cdot 5\end{array}$ & $\begin{array}{l}1922 \text { May } 26 \cdot 0 \\
1923 \text { June } 30 \cdot 0 \\
1924 \text { Aug. } 3 \cdot 0\end{array}$ & $\begin{array}{l}\text { May } 25 \cdot 5 \\
\text { June } 29 \cdot 5 \\
\text { Aug. } 2.5\end{array}$ & $\begin{array}{r}2432400 \cdot 5 \\
2800 \cdot 5 \\
3200 \cdot 5\end{array}$ & $\begin{array}{l}1947 \text { Aug. } 3 \cdot 0 \\
1948 \text { Sept. } 6 \cdot 0 \\
1948 \text { Oct. } 11 \cdot 0\end{array}$ \\
\hline
\end{tabular}

year for each planet. Prof. Lagrula stated that it would be advisable to continue publication each year of the brighter planets. Prof. Leuschner said that the contradiction mentioned by Dr Comrie was only apparent, and that Prof. Fayet had published tables that could be used to obtain approximate positions of minor planets throughout the year (except near conjunction) even if ephemerides were not published. Prof. Fayet expressed his gratification at hearing about the help his tables might give in identifications, although he had made them for other purposes, namely statistical investigation of the system of minor planets, their proximities, etc. The opinion of most of those present, expressed by Dr Comrie, Dr Arend and Prof. Lagrula, was that the ephemerides issued by the Rechen-Institut should be continued for all minor planets; Prof. Kopff said that the Rechen-Institut intended to do so. Prof. Kepinski thought that observations of the different minor planets ought to be better distributed; Prof. Kopff replied that a plan of observation was distributed every year to observatories partaking in organised observations. Dr Comrie spoke further against the proposition on the following grounds: 
(a) Observers are not always capable of using general tables to obtain positions.

(b) They will grudge the time and labour required to consult general tables.

(c) There will be a great deal of duplication of effort.

Dr Crommelin agreed with Dr Comrie. Prof. Leuschner stated that it was not intended that observers themselves should identify the minor planets and use Prof. Fayet's tables. It was decided that no action be taken at the present time, but that the matter should be borne in mind until the next meeting, members being invited to file with the President memoranda stating their opinions.

(8) Prof. Leuschner opened a discussion on a plan of co-operation for the measurement and statistical evaluation of images of faint minor planets appearing on plates taken with powerful telescopes. He outlined the present position, stating that various observers had raised informally the question of the use that might be made of the unmeasured images found by them on photographic plates taken with powerful instruments for other purposes. He said that he had been in correspondence on the subject with Dr Baade at Mount Wilson, who had published statistical results concerning the number of minor planets observable with the Ioo-inch reflector, and had consulted Prof. Fayet on the advisability of organised action. Dr Baade's reply was circulated. In it, after consultation with Nicholson, he expressed interest in the question and referred to Klose's work as indicating possibilities in the direction of statistical investigations concerning minor planets, but stressed that, prior to undertaking adventurous projects, theoretical astronomers should clarify their minds in regard to the problems to be considered by statistical methods and in regard to the nature and extent of the observational material that would be required; otherwise practical results were not to be expected. He did not consider the existing minor planet material as contained, for example, on the plates taken with the roo-inch sufficiently homogeneous to serve statistical purposes. In the meantime experiments might be made by individual effort with certain special homogeneous series, such as his series of plates of N.G.C. I6r3, which will shortly extend over four oppositions, and Hubble's survey of nebulae.

In view of their great importance for the calculation of the orbits of certain celestial objects, Prof. Kamienski and Prof. Kepiński proposed that Commission 20 ask Commission 4 to publish in the almanacs the perturbed elements of the major planets for January I each year. The President suggested that the dates be changed to the accepted fixed epochs of osculation; this was accepted by the proposers. In its original form the proposal was as follows:

Le calcul des éphémérides de certains corps célestes doit être effectué avec toute la précision désirable. Dans ce but il faut calculer les perturbations du mouvement des dits corps d'une manière aussi exacte que possible. Dans certains cas, pour faciliter les calculs des perturbations provenant de Mercure, de Vénus et de la Terre et influant le mouvement de quelques cometes, on a besoin de connaitre les éléments des trois planetes mentionnées plus haut. Ayant en vue ces circonstances aussi bien que le fait que la connaissance des éléments des orbites de toutes les grandes planètes est nécessaire dans certains calculs, nous avons, MM. Kamieński et Kepiński, l'honneur d'adresser au Président la proposition suivante: "La Commission 20 adresse aux directeurs des grands almanachs astronomiques la demande de publier, pour le I janvier de chaque année, les éléments perturbés des orbites des grandes planètes avec l'exactitude de I" (resp. $0^{\prime \prime}$ oor dans le mouvement moyen diurne)."

The President thought it was the duty of the computer himself to calculate these elements, as had been done at Berkeley for Jupiter, but that computers would be 
glad if the almanacs could relieve them of this task. It was agreed that the proposal be submitted to Commission 4 for its consideration rather than as a request.

Prof. Michkovitch proposed that Commission 20 should ask all observers of minor planets that, for at least the two first observations of newly discovered planets, not only the positions but also the daily motion and the magnitude be given. This is in accordance with the practice of a number of observers, for example at Uccle. The proposal received the endorsement of the Commission.

A suggestion of Dr Bower's that Io-day intervals be adopted for ephemerides of minor planets, etc., instead of 8-day intervals as at present; was put forward; action on this was deferred. Dr Bower also suggested changing the Julian Day so that it began at midnight instead of at noon; this proposal brought forth very definite disapproval.

At the close of the meeting Prof. Leuschner said that he had hoped to be able to present a summary of the very valuable reports received from some institutes and observatories. As time was not available he asked the Commission to allow the Secretary and himself to incorporate very brief extracts from these reports in its proceedings. It was agreed that institutes and observatories should be encouraged to follow the example of the Astronomisches Rechen-Institut by publishing reports of their activities from time to time for the information of members of the Commission and other interested astronomers. Dr Delporte agreed that the reports were of very great interest, but warned the Commission against reports containing inaccurate comparisons, such as had actually been published. Prof. Leuschner offered to suggest to institutes and observatories that the reports should be based on accurate documentary evidence.

\section{REPORTS OF INSTITUTES AND OBSERVATORIES}

\section{Astronomisches Rechen-Institut, Berlin-Dahlem; G. Stracke}

This comprehensive report, which has been printed in $A . N .6 \mathrm{ro}$, constitutes a document of historical importance. It relates not only to the work of the institute from I9I0-35, but also to the international co-operation of observers of minor planets, and to the contributions of investigators and computers throughout the world to the material published annually in Kleine Planeten. The primary object of the institute is to provide approximate ephemerides for the systematic observation and for the identification of minor planets. The programme of definitive orbits based on accurate perturbations, adopted by Bauschinger in 1896 , could not be carried out in view of the task of providing orbits and ephemerides for the increasing number of newly discovered planets. In rgro F. Cohn therefore introduced a programme of prediction with an accuracy of $0^{\circ} \cdot 5$ to $\mathrm{I}^{\circ}$ in the geocentric position. Since the death of Cohn in I922, Stracke has continued and perfected this programme.

The report gives a complete account of methods of computation for preliminary and later orbits, approximate special perturbations, and ephemerides, with references to the many practical tables published by the institute to facilitate these computations, promote observational activities, and assist in identifications. The method of empirical correction of elements, particularly of $\mu$ and $M$, much used in the earlier years, has been found inadequate and is practically abandoned. The method of variation of constants by special perturbations used at present is illustrated by the satisfactory representation of observations over a period of 25 
years for the critical planet (372) Palma $\left(\mu=629^{\prime \prime} \cdot 5, i=24^{\circ}, \phi=15^{\circ}\right)$. General perturbations are being adopted to an increasing extent from all available outside sources, the number of planets thus involved at present being 223, and tables for their perturbations have been constructed to 1940 when not available otherwise.

Of great value to the work of the institute and to investigators in general is a card catalogue, which has been in the making over a period of years and has been perfected since I933. It contains: references to all planet observations since I893; collection of observations of all unnumbered and new planets; opposition dates since I870; identification catalogue arranged according to the longitude of the node; alphabetical index of all planet names; elements and constants for machine calculations; for each object also number, name, identities, number of oppositions observed since 1893 , elements beginning with V.R.I. 45 , ephemeris correction at each opposition with the mean anomaly, Jupiter conjunctions from I924-36, and explanatory notes concerning the basis of the elements. About 50 observatories are listed as participating regularly or occasionally in the observational programme.

Three tables illustrate the results attained and the present situation concerning the need for more precise elements or continued observations. While I370 planets were discovered in I80I-I909, Table I shows $3 I_{52}$ new discoveries by years from rgro-34 inclusive. Numbers could be assigned in this period to 6 ro planets, while 532 remain without numbers owing to the uncertainty of their orbits. The total number of numbered planets is r3or, of which $69 \mathrm{r}$ belong to the earlier period. While in I9ro 30 per cent. of the newly discovered planets could be numbered, it is now possible to number only Io per cent. For about half of the new discoveries the observational data are insufficient for an orbit determination. A list of references to the $A . N$. , in which the assigned numbers are published, is given.

In Table II changes of elements made at the Rechen-Institut and elsewhere are recorded by years, as well as the number of ephemerides. The total number of element changes is 3564 from I9II-35, of which about half were made at the Rechen-Institut. In recent years, however, this burden has been taken over to a considerable extent by other institutes and investigators. In I 935 improved elements of IIg out of a total of I66 were furnished from outside sources. Of the IOI4 ephemerides for I935 only I40 were furnished to the Rechen-Institut.

Table III contains for all numbered planets the year of discovery, the number of observed oppositions from I80I-Igog inclusive, the total number of observed oppositions to r935 inclusive, and the last observed opposition. An asterisk is attached to 80 planets that have departed by more than $I^{\circ}$ from their ephemerides. A dagger is attached to nearly 300 planets that have not been observed since I930 or for which fewer than four oppositions have occurred. Of these probably 40 may not be found on account of the uncertainty of their orbits.

\section{Astronomical Institute, Leningrad; B. V. Noumerov and N. Komendantoff}

Three reports are available from Leningrad:

(I) By Noumerov concerning methods of observation and computation and a plan of international co-operation for meridian and photographic observations of minor planets for the determination of systematic corrections to star positions. (Communications by N. Dneprovski relating to meridian observations in both hemispheres have been considered by Commission 8 at various times.) Noumerov discusses Brouwer's programme ( $A . J$. I022, I935), and as a result gives an extended list of 
47 planets in lieu of ro originally proposed by himself and I4 selected by Brouwer. After full discussion at a joint meeting of Commissions 4, 8 and 20 the attitude of the Union with regard to the proposed investigations was expressed in the resolution adopted (see page 282).

(2) By Noumerov concerning the principal recent activities of the Institute, which include among other important contributions: Application of the extrapolation method to nearly 80 planets, as agreed with the Rechen-Institut; continuation of precise special perturbations of Jupiter VIII; study and revision of Bohlin's group method and construction of convenient and practical tables, by Komendantoff; general theory of perturbations in polar co-ordinates to first order and to any degree, by Noumerov; absolute theory of perturbations involving Sundman's variable as independent variable and a group theory for planets with mean motion approximating $45^{\prime \prime}$, by Samoilova. The report also makes reference to Voronoff's (Tashkent) remarkable investigation of the motion of (4) Vesta, since published in part in $A . N .6092-3$ and 6128 (I935). In addition to accurate representation of positions over the whole range of observed oppositions, Voronoff has obtained a new value of Jupiter's mass, considerable corrections, affecting the fifth decimal of the rectangular co-ordinates, to the elements of the Earth's orbit, values for the systematic errors of the declinations and equinox of Boss's Preliminary General Catalogue, and irregularities in the Earth's rotation in good agreement with Brown. He has also corrected errors in the perturbations of the third order of Hill's theory of Jupiter and Saturn, with results similar to, although somewhat less reliable than, those obtained from the theory of Vesta. Discussion of the revision of the elements and theories of the major planets is proposed. Noumerov estimates the error introduced into positions of minor planets by errors in the Sun's co-ordinates to be as high as $3^{\prime \prime}$. (At Berkeley, where a correction to the Sun's longitude is now regularly applied, the error has been found to be as high as $I 5^{\prime \prime}$ for objects approaching close to the Earth.)

(3) By Komendantoff concerning methods and results of planetary work at the Institute, prepared for separate publication at the request of the President of the Commission to supplement the Noumerov report. The report gives an outline of the activities of the Institute during the $I_{5}$ years of its existence (I920-35), of which the following is a brief extract. "The working list of the Astronomical Institute includes at present III planets, mainly those with small daily motion (less than $\left.700^{\prime \prime}\right)$ and, consequently, large perturbations; it includes the planets of the Trojan group. The methods used are the extrapolation of perturbed rectangular co-ordinates, and the extrapolation of polar co-ordinates by Noumerov's method, with consideration of perturbations by Jupiter and Saturn."

A detailed account is given of the various methods of extrapolation adopted for any desired degree of accuracy, including choice of interval, successive approximations, computation of co-ordinates and osculating elements, and the checks used.

Up to the present the extrapolation method has been applied to the perturbed motion of 93 planets, in seven instances for twenty and more years with quite satisfactory results. The accuracy of representation of observations is stated to depend almost exclusively upon the quality of the initial elements.

For the improvement of orbits the Institute has developed and is applying several methods giving corrections to osculating elements or to initial co-ordinates (for two moments). For determining definitive osculating elements observations of not less than four oppositions are generally used, following certain theoretical considerations; this also affords a check on the accuracy of the results. Improved orbits have been derived for at least 70 planets. The success of each orbit correction depends 
largely on the accuracy of the observations, and on the absence of appreciable errors and misprints. With sufficient observations and absence of errors a very satisfactory representation of the oppositions $\left( \pm 0^{8.2}, \pm 2^{\prime \prime}\right)$ is realised. Over a period of years the accuracy is of the order of $\mathrm{o}^{\mathrm{m}} \cdot \mathrm{I}$ and $\mathrm{I}^{\prime}$.

The following are examples of the success of extrapolation on the basis of adopted elements without correction.

\begin{tabular}{|c|c|c|c|c|}
\hline Planet & $\mu^{*}$ & Adopted elements by & $\begin{array}{c}\text { Range of } \\
\text { extrapolation }\end{array}$ & $\begin{array}{l}\text { Largest } \\
\text { residual }\end{array}$ \\
\hline $\begin{array}{l}\text { (279) Thule } \\
\text { (624) Hector }\end{array}$ & $\begin{array}{l}404^{\prime \prime} \\
304^{\prime \prime}\end{array}$ & $\begin{array}{l}\text { Wedemeyer (1907) } \\
\text { Strömgren and Vinter } \\
\text { Hansen (1913) }\end{array}$ & $\begin{array}{l}1905-34 \\
1914-34\end{array}$ & $\begin{array}{r}-2^{\mathrm{s}} \cdot 72(1929) \\
+3^{\mathrm{s}} 89(1921)\end{array}$ \\
\hline (659) Nestor & $298^{\prime \prime}$ & Kristensen (1908) & $1917-32$ & $+4^{\mathrm{s} .73}(1932)$ \\
\hline
\end{tabular}

For the following cases the elements were corrected on the basis of oppositions as indicated.

\begin{tabular}{|c|c|c|c|c|c|c|}
\hline & Planet & $\mu^{*}$ & Basic operations & $\begin{array}{l}\text { Largest } \\
\text { residual }\end{array}$ & $\begin{array}{c}\text { Range of } \\
\text { extrapolation }\end{array}$ & $\begin{array}{l}\text { Largest } \\
\text { residual }\end{array}$ \\
\hline & Hygiea & $635^{\prime \prime}$ & $1920,21,22,23$ & $+2^{\prime \prime} \cdot 2 \quad(1923)$ & $1924-34$ & $+0^{\mathrm{s} .70}(1933)$ \\
\hline & Camilla & $548^{\prime \prime}$ & $1920,22,23,24$ & $+0.55(1924)$ & & $+1^{8} \cdot 93(1930)$ \\
\hline & Hermione & $552^{\prime \prime}$ & $1920,21,22,23,25$ & $+0^{\mathrm{s} .08}(1920)$ & $1928-34$ & $-0^{8.37}(1932)$ \\
\hline & Patientia & $662^{\prime \prime}$ & $1921,22,23,24$ & $-8^{\prime \prime} \cdot 8 \quad(1923)$ & $1927-34$ & $-1^{8.63}(1931)$ \\
\hline & Achilles & $297^{\prime \prime}$ & 9 opp., $1906-29$ & $-0.31(1913)$ & $1930-34$ & $-2^{\prime \prime} \cdot 3 \quad(1931)$ \\
\hline & Ganymede & $817^{\prime \prime}$ & $1924,25,26,27,28$ & $-0^{\mathrm{s}} \cdot 10(1927)$ & 1930-35 & $-0^{s .64}(1935)$ \\
\hline
\end{tabular}

A revision and simplification of Wilson's tables for the group $750^{\prime \prime}$ has been undertaken by Komendantoff; the tables and a manual are in press. The tables of Bohlin for the group 900" have been revised by Radynsky, and those of Block and Osten for perturbations due to Saturn by Komendantoff. By the application of group tables, mean elements and general perturbations have been determined for six planets and corrected on the basis of a limited number of oppositions, as indicated for the following three examples.

\begin{tabular}{|c|c|c|c|c|c|}
\hline Planet & $\mu^{*}$ & Basic oppositions & $\begin{array}{l}\text { Largest } \\
\text { residual. }\end{array}$ & $\begin{array}{l}\text { extrapo- } \\
\text { lation }\end{array}$ & $\begin{array}{l}\text { Largest } \\
\text { residual }\end{array}$ \\
\hline $\begin{array}{l}\text { (22) Calliope } \\
\text { (308) Polyxo } \\
\text { (558) Carmen }\end{array}$ & $\begin{array}{l}715^{\prime \prime} \\
778^{\prime \prime} \\
716^{\prime \prime}\end{array}$ & $\begin{array}{l}5 \text { opp., } 1865-1826 \\
7 \text { opp., } 1891-1928 \\
6 \text { opp., } 1905-1930\end{array}$ & $\begin{array}{l}-3^{8 \cdot 7}(1865) \\
+2^{s \cdot 7}(1922) \\
-12^{* *}(1928)\end{array}$ & $\begin{array}{l}1911-34 \\
1896-33 \\
1908-35\end{array}$ & $\begin{array}{l}+8^{\mathrm{a} .9}(1934) \\
+4^{\mathrm{s} .1}(1930) \\
-13^{* *}(1935)\end{array}$ \\
\hline
\end{tabular}

Noumerov's absolute perturbations in polar co-ordinates are intended to be used for planets with daily motion about $800^{\prime \prime}$.

In view of the simplicity and relative accuracy of the group methods of absolute perturbations, which readily permit the use of observations at very distant epochs, it is desirable that they be applied to minor planets that do not come too close to Jupiter. Therefore, while continuing the traditional work on the numerical perturbations of planets, especially those closest to Jupiter $\left(<600^{\prime \prime}\right)$, the Institute is undertaking also the systematic determination of elements and general perturbations for the brightest planets of the group $750^{\prime \prime}\left(m_{0} \leqslant 10 \cdot 0\right)$ and for the most commensurable planets of this group -a total of about 40 planets.

The extensive report gives complete references, fourteen in all, to the published methods and results.

* From Kleine Planeten, 1935.-A. O. L.

SA U v 


\section{Frankfurter Planeteninstitut; $K$. Boda}

Das Frankfurter Planeteninstitut begann seine Tätigkeit am I. Januar IgI3. Trotz aller Schwierigkeiten konnte ein erheblicher Teil des Arbeitsprogrammes erledigt werden. Dieses bestand darin, für die Kleinen Planeten die Störungen mit einer solche Genauigkeit zu rechnen, dass sie jederzeit wieder photografisch aufgefunden werden können. Es wurden daher Tafeln veröffentlicht zur Berechnung der Planetenstörungen und für eine Anzahl Planeten des I/3 und 2/5 Typus, im ganzen ca. 500 Planeten, die Störungen berechnet, und für $170^{*}$ Planeten verbesserte Elemente gerechnet. Für alle Planeten, deren Elemente verbessert wurden, liegen auch Störungsrechnungen vor, auch für solche, deren Störungen nicht veröffentlicht worden sind. Ausserdem wurden einige Planeten, nämlich 9I, I70, 657 mit grösserer Genauigkeit gerechnet, im wesentlichen in der Absicht, geeignete Methoden der Berechnung zu finden. Der weitere Plan geht dahin, auch für die Planeten des Hekuba-Typus geeignete Störungsausdrücke abzuleiten durch Verschärfung der Konvergenz der Reihen. Bei dieser Gruppe wäre die Zahl der mitzunehmenden Glieder nach den gewöhnlichen Methoden sehr gross, und die Rechnung hierdurch erschwert. Die Grundlagen zur Bearbeitung sind bereits durchgeführt.

\section{University of California, Berkeley Astronomical Department (Students' Observatory); A.O. Leuschner}

The programme of determining general perturbations of the first order by Jupiter and of preparing tables for the twenty-two planets discovered by James $\mathrm{C}$. Watson has been completed by application of the Berkeley Tables, on the basis of remote accurate osculating elements, to the difficult cases which have a mean motion approximately twice that of Jupiter. The Berkeley Tables, which are published in Memoirs of the National Academy of Sciences, I4, Third Memoir (Washington, D. C., I922), take account of perturbations of higher order. Hansen's method, which had first been tried on these planets with approximate elements and first order perturbations, did not yield satisfactory results. A report on this work presented in November I934 to the National Academy of Sciences is printed in abstract in Science, 81, No. 2093 (I935 February 8). It remains to publish in detail the results for ten planets. For the other twelve the general perturbations have been in use since their publication for the ephemerides in Kleine Planeten. The accuracy attained with the Berkeley Tables has prompted the publication of ephemerides for $1935-36$ of eight planets with mean motion approximately twice that of Jupiter. A comparison in four cases with ephemerides computed at Leningrad on the basis of accurate osculating elements of recent date and accurate special perturbations by Jupiter and Saturn proved highly satisfactory (Lick Observatory Bulletin, 469). It may

- The foregoing report contained as an appendix a complete tabulation for each of the I70 planets of the number of oppositions used in the correction of the elements; the period over which these oppositions extended; the maximum outstanding residual in the sense observation minus computation; the source of the basic elements; the reference to the journal in which the elements are published; and the year from which the corrected elements were adopted by the Rechen-Institut in Kleine Planeten. Another tabulation gives the list of the 500 planets for which approximate general perturbations have been computed by the Gylden-Brendel method with a reference to the journal in which the perturbations have been published. It is planned to combine these data with similar results concerning general perturbations in a comprehensive tabulation prior to the next meeting of the Union.-A. O. L. 
therefore be concluded that, except in cases of high eccentricities and inclinations, the planets of this group need no longer be treated by special perturbations.

Research Surveys of the Orbits and Perturbations of Minor Planets I-IOgI from IgoI Jamuary I to I929 June 30 are printed, except for the introductory part, and will soon be issued as Publications of the Lick Observatory, Vol. xIX. The material for their continuation for all the numbered planets to I934 June 30 has been assembled and will be printed at a later date. As the introduction will set forth fully the purposes of the Surveys, it suffices to state that it is hoped that the data contained therein will serve as a basis for the determination of accurate general perturbations with accurate osculating or mean elements, and for the comparative analysis of the value of the various theories for the different groups of planets in the cases where several theories have been applied in the past. The Surveys should also prove useful for statistical and other studies requiring accurate rather than approximate elements, in so far as the former are available.

\section{Observatoire Royal de Belgique, Uccle; E. Delporte}

[At the request of the President a preliminary report was supplemented by a supplementary report. Both reports are here printed.]

\section{Rapport Préliminaire.}

Instruments: L'observatoire d'Uccle dispose en service régulier depuis août I932 d'un double astrographe Zeiss, ouverture $40 \mathrm{~cm}$., foyer $2 \mathrm{~m}$. avec lunette guide de $0^{\mathrm{m} \cdot 20}$ et $3 \mathrm{~m}$. Les plaques de dimension $30 \times 30 \mathrm{~cm}$. couvrent $8 \frac{1}{2}^{\circ}$ de côté, c'est-àdire $68^{\circ}$ degrés carrés. Cet instrument nous permet par ciel normal de détecter les planètes d'éclat $I 4^{\mathrm{m}} \cdot 5$ à $15^{\mathrm{m} \cdot 0}$ (par beau ciel) en pose ordinaire et de $16^{\mathrm{m} \cdot 0}$ par la pose en méthode Trépied-Metcalf. La présence de deux chambres permet, si la chose est désirable, de poser d'un côté en photographie directe et de l'autre côté avec interposition d'un écran jaune $\mathrm{GG}_{11}$ (Schott et Genossen) et plaques spéciales de façon à obtenir l'indice de couleur de petites planètes d'éclat jusqu'à $13^{\mathrm{m}} \cdot \mathrm{o}$. Le service de mesure d'indice de coloration pour les petites planètes et de photométrie en général, est assuré actuellement par notre autre astrographe Zeiss triplet $(30 \mathrm{~cm}$. ouverture et $I^{\mathbf{m}} \cdot 50$ longueur focale).

Programme d'observation: Notre programme comporte toujours en première ligne, la recherche des planètes marquées † dans l'éphéméride de Kleine Planeten de l'Astronomisches Rechen-Institut et également la recherche des planètes pour lesquelles une amélioration d'orbite a été entreprise. Depuis fin 1933, sur ma demande, Prof. Stracke a procédé régulièrement à une répartition des planètes à rechercher, entre les observatoires de Yerkes, Uccle, Heidelberg, Siméis et Johannesburg. Cette répartition, d'accord avec les observatoires précités, donne toute satisfaction. Uccle observe également chaque année une douzaine de planètes anciennes lui désignées par le Bureau de calcul de Léningrad en vue d'amélioration d'orbite. Vous aurez trouvé dans le Bulletin astronomique de l'Observatoire d'Uccle des observations de petites planètes publiées régulièrement, positions approchées et positions précises avec la valeur des dépendances. Ces observations sont publiées trimestriellement. En cours d'observations les résultats sont naturellement envoyés régulièrement par circulaires au Bureau des Télégrammes Astronomiques de København et au Rechen-Institut de Berlin-Dahlem. J'attire attention sur les Bulletins volume $I n^{\circ} 6$ (I932) et $n^{\circ} 9$ (I933) qui renferment, rédigés par mon assistant 
M. le Dr S. Arend, des articles très complets sur la réduction des clichés et des questions qui s'y rapportent:

Sur la détermination des mouvements relatifs d'un astre errant.

Formules relatives à l'orientation du grand cercle de recherche d'un astéroïde.

Réductions de plaques astrophotographiques en coordonnées cartésiennes.

Réductions de plaques astrophotographiques en coordonnées equatoriales.

\section{Rapport succinct sur l'activité du service de recherches des petites planètes à l'Observa-} toire royal de Belgique durant la période I5 juin I930-I5 juin I935.

La période allant pour Uccle de I924 à I929 juin a été une simple mise en train en raison des conditions précaires de travail du début: instrument photographique monté sur un ancien pied exigeant le retournement au méridien; défectuosité du mouvement d'horlogerie d'entraînement qui était usé; absence de machines de mesure de précision.

De juin I929 à juin I930 les observations ont été supprimées pour opérer les transformations nécessaires à la salle d'observation et pour pourvoir la lunette d'un nouveau pied.

En juin I930, à la reprise des recherches, l'outillage comprenait:

(I) L'astrographe triplet de Zeiss $(300 \mathrm{~mm}$., $150 \mathrm{~cm}$.) sur pied coudé de Zeiss et mouvement d'horlogerie à poids et régulateur;

(2) Un comparateur Blink-microscope de Zeiss pour plaque $24 \times 30 \mathrm{~cm}$.

(3) Une machine de mesure de précision à deux vis rectangulaires à pas de

$2 \mathrm{~mm}$. susceptible de donner le micron par lecture des tambours au vernier. Cette machine a une longueur de vis de $20 \mathrm{~cm}$. Elle a été fournie par la Société genevoise.

En juillet I933 un instrument plus puissant est entré en service. C'est un double astrographe Zeiss à objectif à 4 lentilles (400 mm., $200 \mathrm{~cm}$.), avec lunette guide $\left(200 \mathrm{~mm}\right.$., $300 \mathrm{~cm}$.) permettant le choix d'étoiles jusqu'à la $9^{\circ}$ grandeur. A partir de cette date, c'est le double astrographe qui a servi aux observations de recherches d'astéroïdes. L'astrographe triplet a été employé dès I93r également à des observations photographiques-photométriques de petites planètes.

Uccle a donc découvert au cours des cinq ans précités 223 planètes nouvelles dont 30 ont pu être suivies de numérotation à son profit.

Il est à noter que la majorité des planètes trouvées en I934 et I935 sont encore en cours de calculs.*

$\mathrm{Au}$ point de vue théorique, $\mathrm{M}$. Delporte a montré dans différents articles, l'avantage de sa méthode barre-point pour la prise des clichés, surtout dans le cas où une seule chambre photographique est employée, car cette méthode permet la discrimination certaine des fausses images et elle donne pour les planètes non seulement la direction du mouvement mais également le sens de déplacement et une mesure plus certaine dela vitesse. Par contre, cette méthode permet moinsl'estimation d'éclat des objets nouvellement découverts, et une pose ponctuelle à la seconde chambre photographique est préférable puisqu'alors étoile et planète ont la même durée de pose. La précision des mesures est accrue également par la considération de la pose ponctuelle.

A certains moments, Uccle a calculé, pour son usage personnel, des orbites circu-

* A statistical summary covering the period under consideration by years shows that $133^{\circ}$ (I009 precise, 321 approximate) positions were secured of the 223 new planets and 2075 ( 323 precise, 1752 approximate) positions of known planets, a total of 3405 . The 1318 plates do not include those taken in 1931 for Eros.-A. O. L. 
laires pour les objets nouvellement découverts, dans le but d'identification éventuelle avec les planètes connues, et surtout pour tirer une éphéméride permettant de retrouver l'astre après une interruption d'une dizaine de jours.

Il a été reconnu que, au voisinage de l'opposition, la simple extrapolation graphique suffit pour suivre l'astre dans son déplacement. Au voisinage de la station, il est au contraire nécessaire de disposer d'une éphéméride provenant d'une orbite elliptique provisoire. Le calcul d'orbite circulaire n'est donc plus employé que dans le cas d'astéroïdes trouvés loin de l'opposition et pour lesquels les comparaisons avec les données de l'éphéméride des petites planètes, calculé par le Rechen-Institut, ne peut fournir d'identification. M. Arend s'est spécialement occupé du problème de la réduction des clichés astronomiques. Dans les notes détaillées qu'il a publiées à ce sujet, figurent notamment des méthodes nouvelles en ce qui concerne le rattachement d'un astre soit à deux étoiles en se servant de dépendances particulières, soit à 4 ou $n$ étoiles en employant des dépendances généralisées. Il a indiqué récemment quelques formules simples destinées au calcul des mouvements relatifs (propres, apparent et parallactique) d'un astre errant.

Il a aussi apporté une contribution au problème du calcul de l'orientation du grand cercle de recherche des astéroïdes. Ces travaux ont paru principalement dans les Bulletins de l'Observatoire royal de Belgique volume $\mathbf{x} \mathrm{n}^{\circ} 6$ (1932), 9 (1933), I4 (1934); Comptes-rendus de l'Académie des Sciences de Paris (I932), 194 et 195, et Comptes-rendus de la $56^{\circ}$ session de l'Association francaise pour l'avancement des Sciences (I932).

M. Arend a calculé un certain nombre d'orbites elliptiques et d'éphémérides pour des petites planètes découvertes à Uccle. Lors d'un séjour d'instruction au RechenInstitut de Berlin, il a amélioré les orbites des trois astéroïdes I052 Belgica, 975 Perseverantia et 754 Malabar.

MM. Bourgeois et Rigaux depuis I93I ont entrepris l'étude photométrique d'une dizaine d'astéroïdes dont la variabilité est suspectée ou reconnue. Ils ont analysé au point de vue photométrique la série entière des plaques d'Eros prises au cours de l'opposition I930-3I complétant ainsi le travail déjà publié par MM. Delporte et Bourgeois, celui-ci portant sur un ensemble de plaques obtenues au cours de la même nuit.

\section{Observatoire de Siméis: G. Neujmin}

[In Astronomical Journal of the Soviet Union, II, 5, 1934; in the Russian language with a French summary under the title "Résultats et Perspectives du Service des Petites Planetes à l'Observatoire de Simeis". The report covers the period from I912 to 1933.]

Le service photographique des petites planètes, étant inclus dans le programme des travaux de l'observatoire de Siméis dès le commencement de l'année I9I2, se poursuit systématiquement pendant 22 ans. Le présent article contient le résumé général du travail exécuté, et les perspectives possibles y sont évaluées.

Après les informations sur l'organisation, les méthodes et l'exécution du travail sont amenées les données statistiques du travail exécuté. La table I présente les données suivantes pour chaque année séparément:

(I) La quantité de paires de clichés prises pour le service des petites planètes (2007);*

(2) Le nombre général des positions obtenues des planètes (6rog);

* The figures in parentheses have been inserted from the Russian text; those in (I) and (2) are totals and those in (3), (6) and (7) means for the 22 years.-A. O. L. 
(3) Le nombre moyen des positions pour une paire prise $(3 \cdot 0)$;

(4) Le nombre des planètes connues observées;

(5) Le nombre des planètes nouvelles découvertes;

(6) Le rapport du nombre des planètes nouvelles au nombre des connues (0.I4);

(7) La grandeur stellaire moyenne des nouvelles (13.3).

Les tables suivantes éclairent le rôle de l'observatoire de Siméis dans le service international des petites planètes. La table II donne la répartition de toutes les nouvelles planetes découvertes depuis le $I$ janvier I9I2 jusqu'au I juillet I933 d'après les années et les différents observatoires ( $45^{8}$ pour Siméis). La table III présente les mêmes données, mais seulement pour les nouvelles munies d'orbites et ayant reçu de numéros (93 pour Siméis). La table IV présente les données sommaires et le rapport du nombre des planètes numérotées à toutes les nouvelles découvertes à l'observatoire susdit pendant la période envisagée.

L'examen de ces données permet d'arriver à des conclusions suivantes:

(I) Le service des petites planètes est choisi très heureusement pour Siméis conformément à l'instrument et à la situation de l'observatoire.

(2) Cette circonstance de même que l'organisation appropriée du travail et surtout son exécution méthodique pendant une longue série d'années ont permis à Siméis d'accomplir près de $\frac{1}{f}$ du travail d'observation photographique des petites planètes exécuté pendant la durée de son activité et de prendre dans ce domaine la deuxième place parmi les observatoires du monde entier. Il est indispensable de noter que l'astrographe à 5 pouces de Siméis est de beaucoup plus faible que tous les instruments chargés de ce travail dans les autres observatoires.

(3) Depuis le commencement du travail jusqu'au I juillet I933 il a été découvert à Siméis $45^{8}$ planètes nouvelles dont 93 reçurent les éléments certains et entrèrent dans la liste des planètes numérotées.

(4) Il faut constater que le défaut du service des petites planètes à Siméis est comparativement le petit nombre des planètes numérotées, nombre qui aurait pu être augmenté par l'organisation appropriée des calculs rapides des orbites approchées et des éphémérides pour les planètes nouvelles découvertes.

Plus loin le service des petites planètes à Siméis est examiné relativement à son développement historique dans le courant de 22 ans et sont évaluées ses possibilités en connexion avec le changement des objets et des méthodes de recherches.

\title{
COMMISSION 22. (METEORS.)
}

\author{
Acting Président: Mr Felix de Roy. \\ Secretary: Mme G. Camille Flammarion.
}

The Commission first took up the question of the inclusion in their subjects of the Zodiacal Light and related phenomena, and in particular the brightness of the night sky, which had been referred to them by the General Assembly. After some discussion, the following resolution, proposed by the acting President, and seconded by Dr Bosler, was adopted:

I. While, in conformity with the motion voted by them at the Harvard Meeting (Transactions, 4, p. 245), this Commission still consider that it is not desirable that Comets should be added to their subjects, they suggest that, since several of their 